\title{
Implementasi Metode Simple Additive Weighting Dalam Sistem Pendukung Keputusan Penerima Bantuan Program Sembako
}

\author{
Mulia Safitri $^{1)}$, Abertun Sagit Sahay ${ }^{2 *}$, Ariesta Lestari ${ }^{3)}$ \\ 1) 2) 3)Jurusan Teknik Informatika, Fakultas Teknik, Universitas Palangka Raya \\ Jalan Hendrik Timang Kampus UPR Tunjung Nyaho, Palangka Raya \\ *corresponding author \\ ${ }^{1)}$ muliasafitri001@gmail.com \\ 2) abertun@gmail.com \\ 3) aries22ta@gmail.com
}

\begin{abstract}
Abstrak
Kelurahan Pahandut Seberang memiliki tingkat perekonomian masyarakat rata-rata menengah ke bawah, sehingga sebagian besar dari masyarakatnya masih memerlukan bantuan berbasis keluarga dari pemerintah. Di kelurahan pahandut Seberang, dalam seleksi penerima bantuan program sembako masih manual dengan menggunakan kertas. Proses penilaian masih bersifat tidak transparan dan proses penyeleksian ini berjalan sangat lambat dan penerimaan bantuan program sembako menjadi tidak tepat sasaran. Oleh karena itu, untuk mengatasi permasalahan ini maka dibuatlah suatu Sistem Pendukung Keputusan (SPK) yang bisa membantu kelurahan Pahandut Seberang dalam menyeleksi calon penerima bantuan program sembako.

Dalam merancang dan membangun sistem menggunakan 2 metode pengembangan yaitu metode Waterfall sebagai metode pengembangan perangkat lunak dan metode Simple Additive Weighting (SAW) sebagai metode sistem pendukung keputusan pada perhitungannya. Dimana, metode saw memiliki 4 tahapan yaitu menentukan kriteria, menentukan rating kecocokan, membuat matriks keputusan berdasarkan kriteria, melakukan normalisasi matriks. Hasil akhir diperoleh dari hasil perangkingan yaitu penjumlahan dari perkalian matriks ternormalisasi $\mathrm{R}$ dengan bobot sehingga diperoleh nilai terbesar sebagai solusi.

Pengujian sistem ini menggunakan blackbox. Hasil pengujian menunjukkan bahwa sistem yang dibuat telah berjalan sesuai dengan harapan peneliti. Penelitian ini menghasilkan sebuah sistem pendukung keputusan seleksi calon penerima bantuan yang dapat memberikan rekomendasi calon penerima bantuan kepada kelurahan Pahandut Seberang.
\end{abstract}

Keywords : Bantuan Program Sembako, SPK, Waterfall, SAW

\begin{abstract}
Pahandut Seberang Village has an average middle to the lower level of economy in the community, so most of the people still need assistance from the government. In Pahandut Seberang Village, the selection of recipients of the Smbako program assistance is still the old way by using from paper. The assessment process is still not transparent in nature and the selection process is very slow and receipt of Sembako programs assistance are not being on target. Therefore, to overcome this problem, a Decision Support System (SPK) is created to help the Pahandut Seberang Village in selecting the recipients prospective of Sembako program assistance

In designing and building the system are using 2 development methods, namely the Waterfall method as a software development method and the Simple Additive Weighting (SAW) method as a decision support system method in its calculations. Where the saw method has 4 stages, namely determining the criteria, determining the suitability, making a decision matrix based on the criteria and normalizing the. The final result is obtained from the ranking, namely
\end{abstract}


the sum of the normalized matrix multiplication $R$ with the weight vector so that the largest value sas a solution.

This system testing uses a Black-box testing system. The test results show that the system created has been running according to the expectations of the researcher. This research produces a decision support system for selection of the recipients prospective that can provide recommendations for the recipients prospective the Pahandut Seberang village.

\section{Keywords : Sembako Program Assistance, SPK, Waterfall, SAW}

\section{PENDAHULUAN}

Kemiskinan merupakan salah satu persoalan mendasar yang menjadi pusat perhatian pemerintah dinegara manapun. Salah satu aspek penting untuk mendukung Strategi Penanggulangan Kemiskinan adalah tersedianya data kemiskinan yang akurat dan tepat sasaran. Sembako (sembilah bahan pokok) merupakan sembilan kebutuhan pokok masyarakat Indonesia yang terdiri dari makanan atau minuman untuk memenuhi kehidupan sehari-hari yang wajib ada dijual di pasaran.

Kelurahan Pahandut Seberang berada di daerah pinggiran Sungai Kahayan dan masuk dalam wilayah administrasi Kecamatan Pahandut, Kota Palangka Raya, Kalimantan Tengah. Kelurahan Pahandut Seberang memiliki tingkat perekonomian masyarakat rata-rata menengah ke bawah, sehingga sebagian besar dari warga masyarakatnya masih memerlukan bantuan dari pemerintah khususnya untuk program pemerintah bantuan kluster 1 yang berbasis keluarga, guna mengurangi beban ekonomi keluarga. Di kelurahan ini dalam pengambilan keputusan penerima bantuan program sembako masih menggunakan cara manual dan database yang digunakan masih berupa kertas. Selain itu proses penilaian masih bersifat tidak transparan dan proses penyeleksian ini berjalan sangat lambat. Sehingga ada keluarga yang seharusnya tidak memenuhi kriteria untuk mendapatkan bantuan tetapi menerima bantuan program sembako. Sebaliknya terdapat keluarga miskin yang seharusnya mendapatkan bantuan program sembako tetapi tidak mendapatkannya. Hal ini mengakibatkan penerimaan bantuan program sembako menjadi tidak tepat sasaran.

Dalam penelitian tugas akhir ini dibuat sebuah sistem pendukung keputusan untuk menentukan menyeleksi penerima bantuan program sembako. Metode SAW dipilih sebagai metode analisa pendukung keputusan karena terdapat penentuan nilai bobot untuk setiap atribut/kriteria. Dalam metode SAW ini juga dilakukan proses perankingan yang akan menyeleksi alternatif terbaik dari sejumlah alternatif yang ada. Dari hasil perankingan alternatif terbaik adalah keluarga terbaik yang akan dipertimbangkan oleh pengambil keputusan untuk memperoleh bantuan program sembako.

Adapun tujuan dari penelitian ini adalah untuk Menghasilkan sebuah sistem pendukung keputusan yang dapat membantu kelurahan Pahandut Sebrang dalam proses seleksi penerima bantuan sembako sesuai dengan keadaan ekonomi warganya yang berada di garis ketidakmampuan dengan menggunakan metode Simple Additive Weighting.

\section{TINJAUAN PUSTAKA}

\subsection{Sistem Pendukung Keputusan (SPK)}

Sistem pendukung keputusan merupakan suatu system informasi berbasis computer yang menghasilkan berbagai alternative keputusan untuk membantu manajemen dalam menangani berbagai permasalahan yang terstruktur ataupun tidak terstruktur dengan menggunakan data atau model [1].

\subsection{Simple Additive Weighting (SAW)}

Metode SAW adalah metode penjumlahan bobot dari kinerja setiap objek-objek yang berbeda dan memiliki kesempatan yang sama pada semua krieria yang dimiliki. Metode SAW memerlukan proses normalisasi matriks keputusan (X) ke suatu skala yang dapat dibandingkan 
dengan semua alternatif rating yang ada. Metode SAW dapat membantu dalam pengambilan keputusan suatu kasus, akan tetapi perhitungan dengan metode SAW hanya akan menghasilkan nilai terbesar yang akan terpilih sebagai alternatif yang terbaik. Perhitungan akan sesuai dengan metode ini apabila alternatif yang terpilih memenuhi krieria yang telah ditentukan [2].

Berikut ini adalah rumus metode SAW:

$$
R i j=\left\{\begin{array}{lr}
\frac{X i j}{M a x X i j} & \text { Jika } \mathrm{j} \text { atribut keuntungan (benef } i t) \\
\frac{\operatorname{Min} X i j}{X i j} & \text { Jika j atribut biaya (cost) }
\end{array}\right.
$$

Keterangan:

$$
\begin{aligned}
& \mathrm{r}_{\mathrm{ij}} \quad=\text { rating kinerja ternormalisasi } \\
& \operatorname{Max} \mathrm{X}_{\mathrm{ij}}=\text { nilai maximum dari setiap baris dan kolom } \\
& \text { Min } X_{i j}=\text { nilai minimum dari setiap baris dan kolom } \\
& \mathrm{X}_{\mathrm{ij}} \quad=\text { baris dan kolom matriks } \\
& \text { Benefit }=\text { jika nilai terbesar adalah terbaik } \\
& \text { Cost }=\text { jika nilai terkecil }
\end{aligned}
$$

Dengan $\mathrm{r}_{\mathrm{ij}}$ adalah ranting kinerja ternomalisasi dari alternatif Ai pada atribut $\mathrm{Cj} ; \mathrm{I}=1,2, \ldots . \mathrm{m}$ dan $\mathrm{j}=1,2, \ldots$. . Nilai preferensi untuk setiap alternatif (Vi) diberikan sebagai:

$$
\mathrm{Vi}=\sum_{j=1}^{n} \mathrm{WjRij}
$$

Keterangan:

$\mathrm{V}_{\mathrm{i}}=$ rangking untuk setiap alternatif

$\mathrm{W}_{\mathrm{j}}=$ nilai bobot dari setiap kriteria

$\mathrm{R}_{\mathrm{ij}}=$ nilai rating kinerja ternormalisasi

Nilai $V_{i}$ yang lebih besar mengindikasikan bahwa alternatif $A_{i}$ lebih terpilih.

\subsection{Program Sembako}

Dalam buku (Pedoman Umum Program Sembako 2020), Program Sembako merupakan pengembangan dari program Bantuan Pangan Nontunai (BPNT) sebagai program transformasi bantuan pangan untuk memastikan program menjadi lebih tepat sasaran, tepat jumlah, tepat waktu, tepat harga, tepat kualitas, dan tepat administrasi. Program Sembako diharapkan dapat memberikan pilihan kepada penerima manfaat dalam memilih jenis, kualitas, harga dan tempat membeli bahan pangan.

\subsection{WEB}

Website adalah kumpulan dari halaman web yang sudah dipublikasikan di jaringan internet dan memiliki domain/URL (Uniform Resource Locator) yang dapat diakses semua pengguna internet dengan cara mengetik alamatnya [3].

\section{METODE PENELITIAN}

\subsection{Metode Pengumpulan Data}

Metode pengmpulan data digunakan melakukan analisis kebutuhan Sistem serta alat dan bahan yang dibutuhkan dalam mencapai tujuan penelitian. Metode pengumpulan data yang digunakan dalam penelitian ini yaitu observasi, wawancara, studi pustaka. Dari metode pengumpulan data maka didapatkan kriteria masyarakat tidak mampu, penerima bantuan masih belum tepat sasaran dan beberapa referensi dalam mendukung penelitian. 


\subsection{Metode Pengembangan Perangkat Lunak}

Metodologi pengembangan dalam pembuatan sistem informasi menggunakan waterfall system menurut Sommerville (2011: 30).

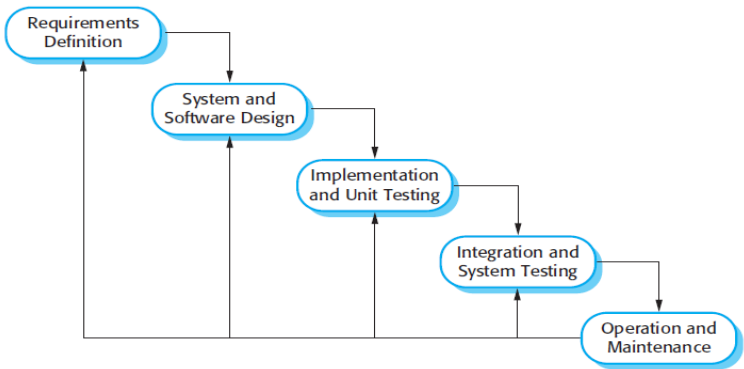

Gambar 1 Diagram Alur Metodologi Waterfall (Sommerville, 2011)

\section{Requirements Definition}

Pada tahap peneliti ini melakukan analisis sistem yang sedang berjalan, melakukan wawancara langsung pegawai kelurahan mengenai permasalahan yang ada dan tujuan perancangan sistem baru, merancang batasan sistem serta kebutuhan yang diperlukan untuk pembuatan sistem. Kemudian peneliti memberikan sistem usulan dari masalah yang ada untuk dibuatkan sistem yang baru.



Gambar 2 Flowchart Sistem

2. System and Software Design

Dari usulan sistem yang baru, pada tahap ini peneliti melakukan perancangan sistem mulai dari desain sistem menggunakan Data Flow Diagram (DFD) sebagai alat pembuatan model dan merancang desain database menggunakan Entity Realtionship Diagram (ERD) yang digunakan untuk menjelaskan relasi antar data dalam basis data. 
1. DFD Diagram Konteks dan DFD Level 1

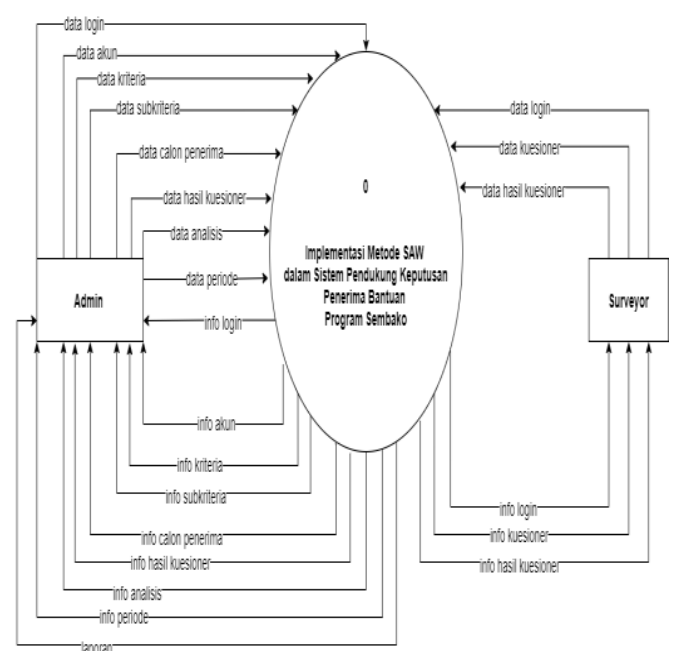

Gambar 3 Diagram Konteks

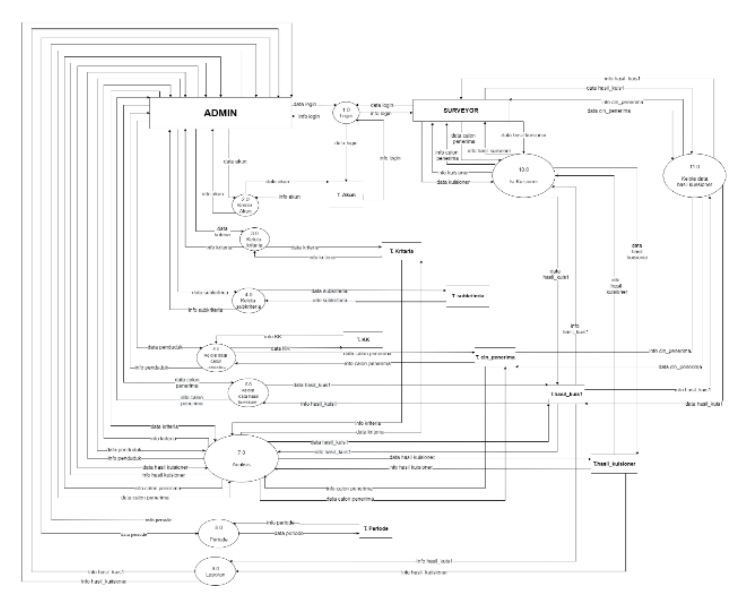

Gambar 4 DFD Level 1

\section{Entity Relationship Diagram}



Gambar 5 Entity Relationship Diagram

\section{Implementation and Unit Testing}

Pada tahap ini peneliti merealisasikan rancangan sistem pada tahap sebelumnya ke dalam bahasa pemrograman Hypertext Preprocessor (PHP) dan basis data My Structured Query Language (MySQL) menjadi suatu unit program. Kemudian unit program yang telah dibuat tadi dilakukan pengujian untuk mengetahui apakah program sudah berjalan sesuai dengan yang diharapkan peneliti.

4. Integration and System Testing

Setelah pengujian unit program, pada tahap ini peneliti melakukan pengujian kembali terhadap tiap-tiap unit program menjadi satu kesatuan program hingga sesuai dengan yang diharapkan. Peneliti melakukan pengujian menggunakan jenis pengujian black-box. untuk mengetahui apakah fungsi-fungsi, masukan, dan keluaran dari perangkat lunak sesuai dengan spesifikasi yang dibutuhkan. 


\section{Operation and Maintenance}

Setelah sistem selesai diuji dan kemudian diberikan ke pengguna sistem (dalam hal ini pengguna sistem adalah pegawai Kelurahan), pada tahap ini pegawai Kelurahan mulai mengoperasikan sistem. Sehingga peneliti hanya melakukan hingga tahap Integration and System Testing saja.

\subsection{Metode Simple Additive Weighting}

Metode yang digunakan dalam pembuatan sistem ini yaitu metode Simple Additive Weighting. Berikut ini tahapan dari implementasi simple additive weighting.

1. Menentukan kriteria yang akan dijadikan acuan dalam pengambilan keputusan, yaitu $\mathrm{C}_{\mathrm{i}}$.

Tabel 1 Kriteria

\begin{tabular}{|c|c|c|c|}
\hline Kriteria & Keterangan & Bobot & Atribut \\
\hline C1 & Jumlah Tanggungan & 10 & Benefit \\
\hline $\mathrm{C} 2$ & Penghasilan & 10 & Benefit \\
\hline C3 & Pendidikan & 6 & Benefit \\
\hline $\mathrm{C} 4$ & Luas bangunan & 6 & Benefit \\
\hline C5 & Jenis lantai & 6 & Benefit \\
\hline C6 & Jenis dinding & 6 & Benefit \\
\hline C7 & Fasilitas buang air besar & 8 & Benefit \\
\hline C8 & Daya listrik & 10 & Benefit \\
\hline C9 & Sumber air minum & 6 & Benefit \\
\hline $\mathrm{C} 10$ & Aset Pribadi & 10 & Benefit \\
\hline C11 & Pengobatan & 8 & Benefit \\
\hline C12 & Kesanggupan makan per hari & 8 & Benefit \\
\hline $\mathrm{C} 13$ & Bahan bakar memasak & 6 & Benefit \\
\hline Total & & 100 & \\
\hline
\end{tabular}

Gambar 6 Kriteria dan Bobot Kriteria

2. Menentukan rating kecocokan setiap alternatif pada setiap kriteria.

Tabel 2 Rating Kecocokan

\begin{tabular}{|l|c|c|c|c|c|c|c|c|c|c|c|c|c|}
\hline \multirow{2}{*}{ Alternatif } & \multicolumn{10}{|c|}{ Kriteria } \\
\cline { 2 - 17 } & C1 & C2 & C3 & C4 & C5 & C6 & C7 & C8 & C9 & C10 & C11 & C12 & C13 \\
\hline A1 & 3 & 3 & 2 & 3 & 3 & 2 & 1 & 4 & 1 & 2 & 2 & 2 & 2 \\
\hline A2 & 1 & 3 & 2 & 3 & 3 & 2 & 1 & 4 & 1 & 2 & 1 & 1 & 2 \\
\hline A3 & 2 & 3 & 3 & 3 & 3 & 3 & 4 & 4 & 1 & 2 & 2 & 2 & 2 \\
\hline A4 & 2 & 4 & 3 & 4 & 3 & 3 & 1 & 4 & 1 & 2 & 2 & 2 & 2 \\
\hline A5 & 2 & 2 & 1 & 3 & 1 & 1 & 1 & 2 & 1 & 2 & 1 & 1 & 2 \\
\hline A6 & 2 & 3 & 3 & 4 & 3 & 3 & 4 & 4 & 1 & 2 & 2 & 2 & 2 \\
\hline A7 & 4 & 3 & 5 & 4 & 3 & 3 & 4 & 4 & 1 & 2 & 3 & 2 & 2 \\
\hline A8 & 3 & 2 & 5 & 4 & 3 & 3 & 4 & 4 & 1 & 2 & 2 & 2 & 2 \\
\hline A9 & 4 & 4 & 4 & 4 & 3 & 3 & 1 & 4 & 1 & 2 & 2 & 2 & 2 \\
\hline A10 & 1 & 2 & 1 & 2 & 2 & 2 & 1 & 3 & 1 & 2 & 1 & 1 & 2 \\
\hline A11 & 1 & 1 & 1 & 3 & 2 & 1 & 1 & 3 & 1 & 1 & 1 & 1 & 2 \\
\hline A12 & 2 & 3 & 3 & 3 & 3 & 3 & 4 & 4 & 1 & 2 & 2 & 2 & 2 \\
\hline A13 & 3 & 3 & 5 & 3 & 3 & 3 & 4 & 4 & 1 & 2 & 2 & 2 & 2 \\
\hline A14 & 4 & 3 & 3 & 3 & 3 & 3 & 4 & 3 & 1 & 2 & 2 & 2 & 2 \\
\hline A15 & 2 & 1 & 1 & 2 & 2 & 2 & 1 & 2 & 1 & 1 & 1 & 1 & 1 \\
\hline
\end{tabular}

3. Membuat matriks keputusan berdasarkan kriteria $\left(\mathrm{C}_{\mathrm{i}}\right)$, kemudian melakukan normalisasi matriks berdasarkan persamaan yang disesuaikan dengan jenis atribut (atribut keutungan ataupun atribut biaya) sehingga diperoleh matriks ternormalisasi r. 


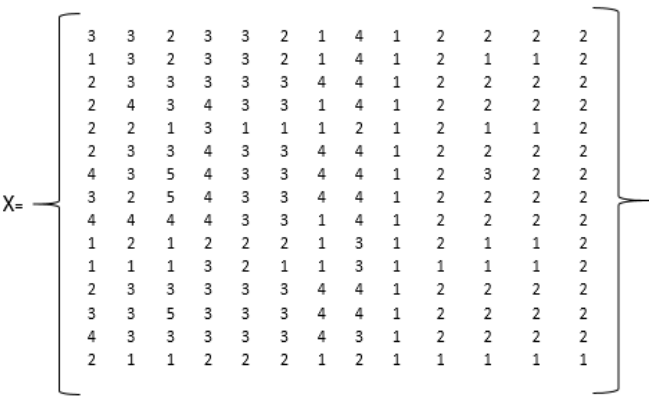

Gambar 6 Matriks Keputusan

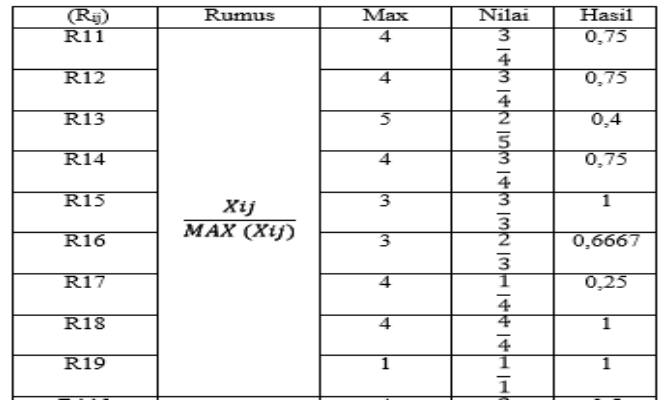

Gambar 7 Normalisasi Matriks

Tabel 3 Hasil Normalisasi

\begin{tabular}{|c|c|c|c|c|c|c|c|c|c|c|c|c|c|}
\hline \multirow{3}{*}{ Alternatif } & \multicolumn{13}{|c|}{ Kriteria } \\
\hline & C1 & $\mathrm{C} 2$ & $\mathrm{C} 3$ & $\mathrm{C} 4$ & C5 & C6 & C7 & $\mathrm{C8}$ & C9 & C10 & C11 & C12 & C12 \\
\hline & 10 & 10 & 6 & 6 & 6 & 6 & 8 & 10 & 6 & 10 & 8 & 8 & 6 \\
\hline A1 & 0,75 & 0,75 & 0,4 & 0,75 & 1 & 0,67 & 0,25 & 1 & 1 & 0,5 & 0,67 & 0,67 & 1 \\
\hline A2 2 & 0,25 & 0,75 & 0,4 & 0,75 & 1 & 0,67 & 0,25 & 1 & 1 & 0,5 & 0,33 & 0,33 & 1 \\
\hline A3 & 0,5 & 0,75 & 0,6 & 0,75 & 1 & 1 & 1 & 1 & 1 & 0,5 & 0,67 & 0,67 & 1 \\
\hline A4 & 0,5 & 1 & 0,6 & 1 & 1 & 1 & 0,25 & 1 & 1 & 0,5 & 0,67 & 0,67 & 1 \\
\hline A5 & 1 & 0,75 & 0,6 & 1 & 1 & 1 & 1 & 1 & 1 & 0,5 & 0,67 & 0,67 & 1 \\
\hline A6 & 0,5 & 0,25 & 0,4 & 0,5 & 0,67 & 0,33 & 0,25 & 0,5 & 1 & 0,25 & 0,33 & 0,33 & 0,5 \\
\hline A7 7 & 1 & 0,75 & 1 & 1 & 1 & 1 & 1 & 1 & 1 & 0,5 & 1 & 0,67 & 1 \\
\hline A8 & 0,75 & 0,5 & 1 & 1 & 1 & 1 & 0,25 & 1 & 1 & 0,5 & 0,67 & 0,67 & 1 \\
\hline A9 & 1 & 1 & 0,8 & 1 & 1 & 1 & 0,25 & 1 & 1 & 1 & 0,67 & 0,67 & 1 \\
\hline A10 & 0,25 & 0,5 & 0,2 & 0,5 & 0,67 & 0,67 & 0,25 & 0,75 & 1 & 0,5 & 0,33 & 0,33 & 1 \\
\hline A11 & 0,25 & 0,25 & 0,2 & 0,75 & 0,67 & 0,33 & 0,25 & 0,75 & 1 & 0,25 & 0,33 & 0,33 & 1 \\
\hline A12 & 0,75 & 0,75 & 0,4 & 1 & 1 & 1 & 1 & 1 & 1 & 0,5 & 0,67 & 0,67 & 1 \\
\hline A13 & 0,75 & 0,75 & 1 & 0,75 & 1 & 1 & 1 & 1 & 1 & 0,5 & 0,67 & 0,67 & 1 \\
\hline A14 & 1 & 0,75 & 0,6 & 0,75 & 1 & 1 & 1 & 0,75 & 1 & 0,5 & 0,67 & 0,67 & 1 \\
\hline A15 & 0,5 & 0,25 & 0,2 & 0,5 & 0,67 & 0,67 & 0,25 & 0,5 & 1 & 0,25 & 0,33 & 0,33 & 0,5 \\
\hline
\end{tabular}

4. Hasil akhir diperoleh dari hasil perangkingan yaitu penjumlahan dari perkalian matriks ternormalisasi $\mathrm{R}$ dengan vector bobot sehingga diperoleh nilai terbesar yang dipilih sebagai alternatif terbaik $\left(\mathrm{A}_{\mathrm{i}}\right)$ sebagai solusi.

$$
\begin{aligned}
V_{1}=\{( & (10 \times 0,75)+(10 \times 0,75)+(6 \times 0,4)+ \\
& (6 \times 0,75)+(6 \times 1)+(6 \times 0,67)+ \\
& (8 \times 0,25)+(10 \times 1)+(6 \times 1)+ \\
& (10 \times 0,5)+(8 \times 0,67)+(8 \times 0,67) \\
+ & (6 \times 1) \\
= & (7,5+7,5+2,4+4,5+6+4+2 \\
& +10+6+5+5,36+5,36+6) \\
= & 71,62
\end{aligned}
$$

Tabel 4 Hasil Akhir

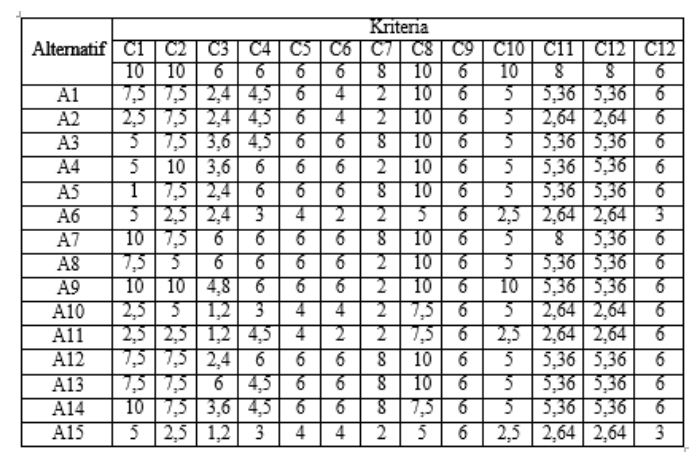

Tabel 5 Hasil Ranking

\begin{tabular}{|c|c|c|c|}
\hline \multicolumn{1}{|l|}{ No } & AL TERNATIF & Nilai akhir & Rangking \\
\hline 1. & A1 & 71,62 & 10 \\
\hline 2. & A2 & 61,62 & 11 \\
\hline 3. & A3 & 78,32 & 7 \\
\hline 4. & A4 & 76,32 & 8 \\
\hline 5. & A5 & 84,82 & 3 \\
\hline 6. & A6 & 81,12 & 5 \\
\hline 7. & A7 & 89,86 & 1 \\
\hline 8. & A8 & 76,22 & 9 \\
\hline 9. & A9 & 87,52 & 2 \\
\hline 10. & A10 & 51,54 & 12 \\
\hline 11. & A11 & 46 & 13 \\
\hline 12. & A12 & 78,32 & 7 \\
\hline 13. & A13 & 83,22 & 4 \\
\hline 14. & A14 & 80,82 & 6 \\
\hline 15. & A15 & 43,52 & 14 \\
\hline
\end{tabular}




\section{PEMBAHASAN}

Setelah desain sistem dan perangkat lunak selesai dibuat, desain direalisasikan ke dalam bahasa pemrograman PHP, kemudian dilakukan pengujian terhadap website yang dibuat dengan tujuan untuk memastikan bahwa setiap fitur dapat berfungsi dengan baik dan sesuai dengan kebutuhan pengguna.



Gambar 8 Halaman Login
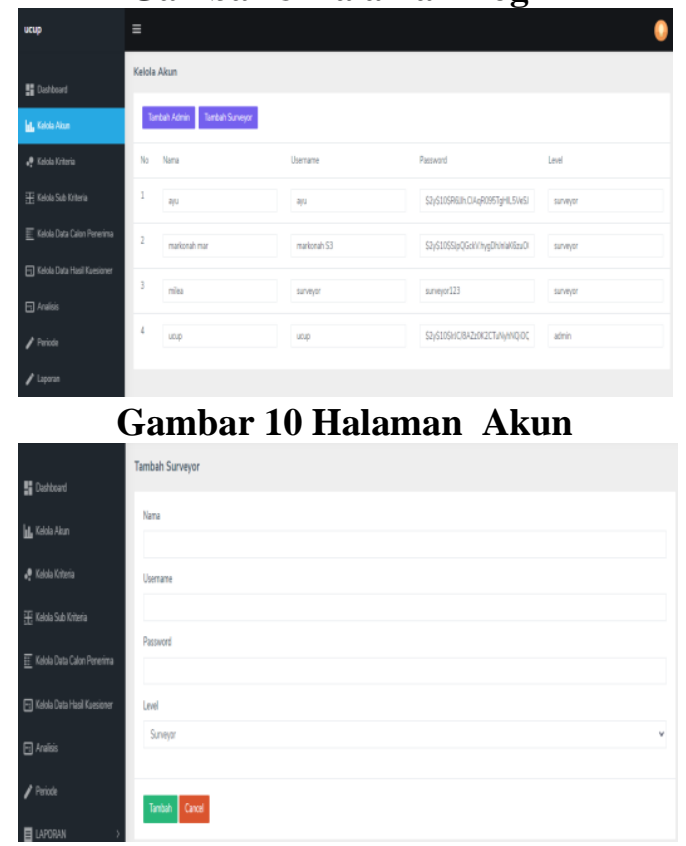

Gambar 12 Tambah Surveyor

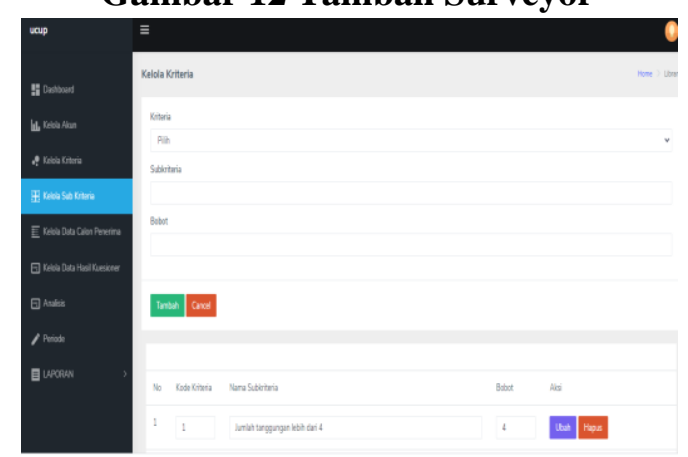

Gambar 14 Kelola Sub Kriteria

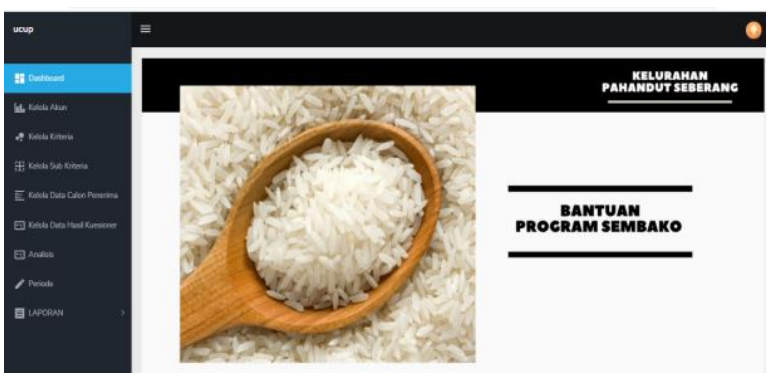

Gambar 9 Halaman Utama



Gambar 11 Halaman Tambah Admin

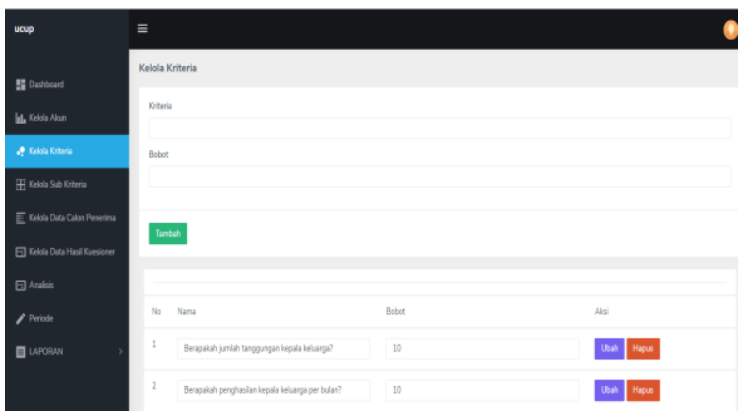

Gambar 13 Kelola Kriteria

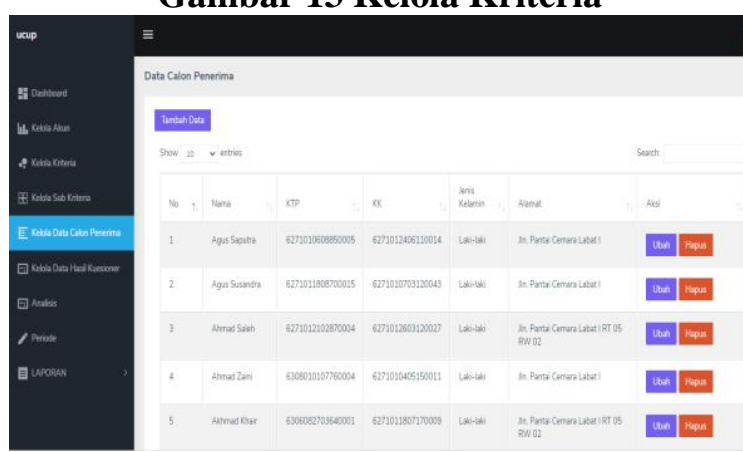

Gambar 15 Kelola Data Calon Penerima 




Gambar 16 Hasil Kuesioner

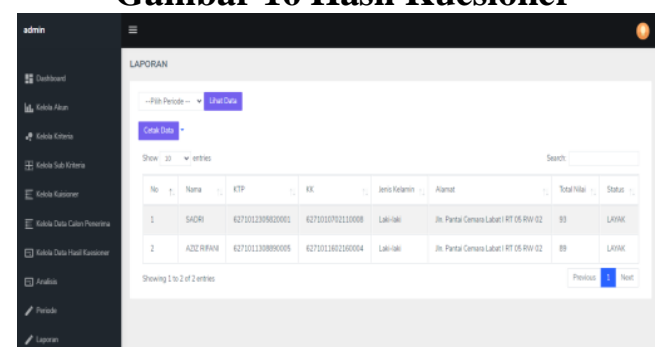

Gambar 18 Halaman Laporan

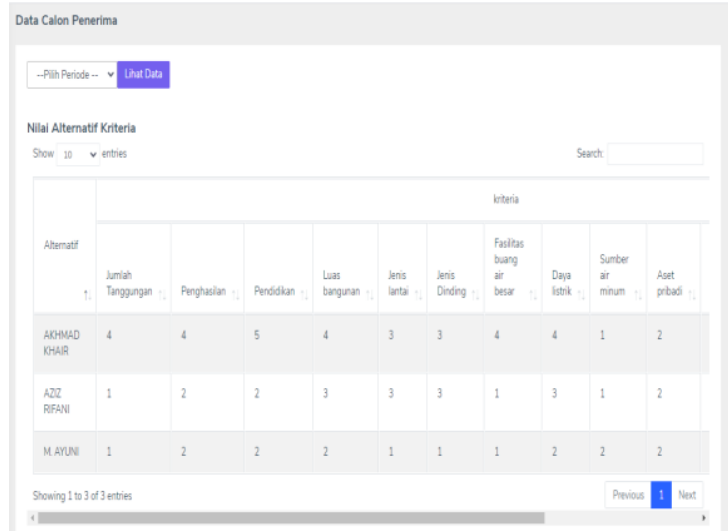

Gambar 17 Analisis

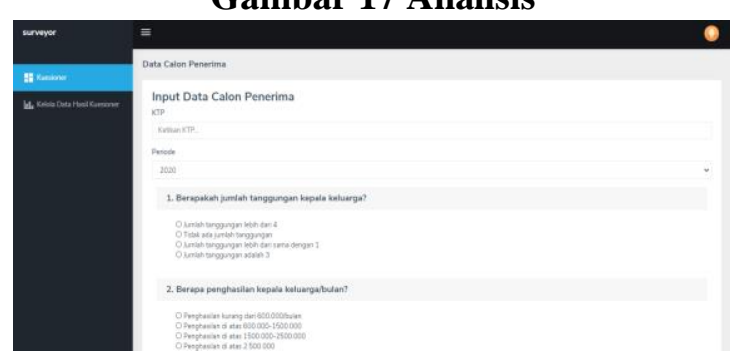

Gambar 19 Kuesioner (surveyor)

\section{KESIMPULAN}

Kesimpulan dari penelitian yang telah dilaksanakan adalah sistem ini dirancang menggunakan 2 metode pengembangan yaitu metode Waterfall sebagai metode pengembangan perangkat lunak dan metode Simple Additive Weighting (SAW) sebagai metode sistem pendukung keputusan.

Kemudian pada perhitungannya. perhitungan seleksi calon penerima bantuan pada sistem pendukung keputusan menggunakan Metode Simple Additive Weighting (SAW) memiliki 4 tahapan dan hasil perhitungan yang dilakukan baik secara manual maupun sistem dengan menggunakan kriteria sebanyak 13 kriteria dan 47 subkriteria dengan masing-masing bobotnya. Jumlah pendaftar calon penerima bantuan tahun 2020 sebanyak 94 orang, terdapat 70 orang calon penerima bantuan yang layak menerima bantuan profram sembako. Sedangkan 24 orang lainnya dengan status tidak layak mendapatkan bantuan dengan bobot nilai akhir kurang dari 60 dengan range bobot nilai akhir 1-100. Sehingga didapatkan bahwa implementasi metode SAW dalam sistem pendukung keputusan bantuan program sembako dapat memberikan rekomendasi dengan hasil akhir layak dan tidak layak, baik melalui perhitungan manual maupun system.

\section{DAFTAR PUSTAKA}

[1] Pratiwi, Heny. 2016. Buku Ajar Sistem pendukung Keputusan Ed-1. Yogyakarta: Deepublish.

[2] Fatkhurrochman \& Dwi Astuti. 2018. Analisis Perbandingan Metode Topsis Dan Saw Dalam Penentuan Penerima Bantuan Pembangunan Rumah Masyarakat Kurang Maтри. Jurnal Seminar Nasional Teknologi Informasi dan Multimedia 2018. Yogyakarta: Universitas AMIKOM Yogyakarta.

[3] Shalahuddin. M \& Rosa A.S. 2018. Rekayasa Perangkat Lunak Terstruktur dan Berorientasi Objek. Bandung : Informatika Bandung 
[4] Kusumawati, Dewi \& Mohammad. 2018. Sistem Pendukung Keputusan Penerimaan Bantuan Beras Miskin Menggunakan Metode Ahp (Analytical Hierarchy Process) Pada Kecamatan Banawa. Jurnal. Jurnal Informatika dan Ilmu Komputer. Volume : 1, No : 2. Palu: STIMIK Bina Mulia Palu.

[5] Rini, Aning Setiya dan Dewi Soyusiyawati. 2014. Sistem Pendukung Keputusan Seleksi Penerimaan Beras Untuk Keluarga Miskin Dengan Metode Simple Additive Weighting. Jurnal. Jurnal Sarjana Teknik Informatika. Volume : 2, No : 2. Yogyakarta: Universitas Ahmad Dahlan 